\title{
ПЕРСПЕКТИВА ЗАСТОСУВАННЯ ТЕХНОЛОГІЯ «БЛОКЧЕЙН» В КОНТЕКСТІ ФОРМУВАННЯ І РОЗВИТКУ ДЕРЖАВИ
}

\begin{abstract}
Анотація. В даній статті досліджена одна з найсучасніших технологій - технологія "блокчейн". Першочергово вивчена технічна сторона технологічної блокчейну. Також досліджено правовий аспект даного питання, а саме юридичне регулювання блокечейну як технології та всіх аспектів її застосування, для формування загального розуміння фрункціонування технології у повсякденні. Наступним було вивчено питання застосування технології блокчейн на різних рівнях, в тому числі на державному, і відповідно було досліджено успішний зарубіжний та вітчизняний досвід. Окремо досліджена вирішення проблеми людського фактору у людських правовідносинах за допомогою блокчейну. За результатами дослідження було сформульовано висновки про перспективність даної технології та визначено проблемні моменти їі застосування на сучасному етапі.
\end{abstract}

Ключові слова: блокчейн, технології, державотворення, право, реформа.

Dumchikov Mikhail, Shevtsov Yaroslav Sumy State University

\section{PROSPECTS FOR APPLYING BLOCKCHAIN TECHNOLOGY IN THE CONTEXT OF STATE FORMATION AND DEVELOPMENT}

Summary. Today, in the digital age, along with the economic and legal aspects, technology is actively implemented in all spheres and branches of politics and, accordingly, human life. Now technological progress has a number of important achievements. One of the "most important" technological achievements is the creation of blockchain technology. This technology is undoubtedly complex in its essence, but it has a huge potential for application, especially in the context of important, large-scale issues such as state creation. This technology is already used all over the world, including to ensure the organization and functioning of the state. In addition, this technology is already able to guarantee the safety of introducing technological innovations into the state apparatus, and perhaps it will become the key to solving the problem of the human factor in public legal relations. This article examines one of the most modern technologies - the "blockchain"technology. First of all, the technical side of the blockchain technology category is studied at the basic level. The legal aspect of this issue, namely the legal regulation of blockchain as a technology and all aspects of its application, is also studied to form a common understanding of the functioning of technology in everyday life. Next, the issue of applying blockchain technology at various levels, including at the state level, was studied, and, accordingly, successful foreign and domestic experience was investigated. A special part of the study was the issue of solving the problem of the human factor in human legal relations and the corresponding capabilities of blockchain technology in the introduction of modern technologies in the processes of formation and development of the state. Based on the results of the study, conclusions were formulated about the prospects of this technology, and accordingly, the most promising ways and methods of its application were identified. In addition, the specifics of using blockchain technology in solving the problem of the human factor in human legal relations, in particular in the public sphere, were determined. The problematic aspects of application at this technology at the current stage of development were also identified.

Keywords: blockchain, technology, state creation, law, reform.

$\Pi$ остановка проблеми. Наразі, в усьому світі триває технологічний розвиток і прогрес. Передові держави знаходять застосування технологіям на найвищому рівні. Однією з найперспективніших таких технологій є блокчейн, який може забезпечити вирішення цілого ряду сучасних проблем державотворення і функщіонування, при цьому, зараз дана технологія в Україні широкого застосунку не знайшла.

Аналіз останніх досліджень і публікацій. Дана тема є дуже актуальною, через що, наразі, налічуеться велика кількість публікацій які різнобічно досліджують технологію блокчейну. Окремо хотілося б виділити роботи В. Шемшученко і О. Бондаренко.

Виділення не вирішених раніше частин загальної проблеми. Наразі немає жодної роботи яка б цілісно досліджувала питання блокчейну, одночасно 3 перспективними шляхами його застосування і розвитку на рівні держави.
Мета статті. Головною метою цієї роботи є дослідження технології блокчейну та перспективи iï застосування в контексті державотворення та фрункціонування держави.

Виклад основного матеріалу. Технологія блокчейн на перший погляд дуже складна, однак це не так. Для розуміння контексту необхідно розуміти технічну сторону питання, відповідно до чого, блокчейн, як технологія являе собою ланцюжок блоків, кожен з яких пов'язаний між собою, самими блоками є цифррові пристрої (комп'ютери, сервери, на яких створюеться, зберігається та обробляється інформація). Такі блоки містять інформацію, яку постійно передають один одному, тим самим захищаючи їі цілісність та попереджають можливість втручання у інформаційні процеси. Таким чином, блоки містять індормацію та захищають іiі від зовнішнього втручання, а сама система ланцюжків реалізовує ці функції, постійно передаючи, оновлюючи інформацію, перевіряючи та віднов- 
люючи іï «правильний» (визначений власником, розпорядником) зміст. На практищі, складним для буденного розуміння технології «блокчейн» $\epsilon$ саме її юридичний аспект, правове регулювання питання, що безпосередньо пов'язано з їі практичним застосуванням. Тут же в знаки дається одна 3 найбільших правових проблем сучасності. Справа в тому, що незважаючи на історичні особливості розвитку, а також значення цифрових технологій для людства, юридична сторона їх фрункціонування та взагалі правове регулювання всіх технологічних мереж, систем та процесів не є достатнім. Особливо це стосується країн колишнього СРСР, в тому числі України. Вітчизняна правова система досить поверхнево регулює навіть старі технологічні питання, не кажучи про «новітню» технологію «блокчейн» $[1 ; 2 ; 5 ; 6 ; 12]$.

Наразі, дане питання досить поверхнево регулюеться кількома нормативно-правовими актами. До основних можна віднести Закону України (далі - ЗУ) «Про телекомунікації», в чинній його редакції. Відповідно до положень џого закону блокчейну можна надати офріщійного визначення, як «телекомунікаційній мережі», тобто комплексу технічних засобів телекомунікацій та споруд, призначених для маршрутизації, комутації, передавання та/або приймання знаків, сигналів, письмового тексту, зображень та звуків або повідомлень будь-якого роду по радіо, провідних, оптичних чи інших електромагнітних системах між кінцевим обладнанням (ч. 1 ст. 1 ЗУ «Про телекомунікації). Звісно, досить загально і поверхнево, однак закон дає нормативне визначення даної категорії, відповідно до чого можна визначити наступні важливі правові аспекти питання. Перш за все, це те, що наразі до блокчейна застосовуються усі загальні положення ЗУ «Про телекомунікації, інших нормативно-правових актів що регулюють суспільні відносини у сфері електроніки та цифрових технологій тощо. Фактично, правове регулювання технології блокчейн та її застосування наразі зводиться до правила, що дозволено робити все, що прямо не заборонено законом $[1 ; 2 ; 12]$.

Досить џікавим, $є$ питання захищеності технології блокчейн. По-перше, суть самої технології полягає в надійності та власній цифровій захищеності. На фоні цього, юридичний (правовий) захист систем блокчейн (ix вмісту) носить другорядний характер. Відповідно до чого, на діяльність блокчейн технології поширюються положення статей 361-363-1 Розділу XVI Кримінального кодексу України - «Кримінальні правопорушення у срері використання електронно-обчислювальних машин (комп'ютерів), систем та комп'ютерних мереж і мереж електрозв'язку». Дуже цікавий момент полягає у тому, що у випадку з блокчейном, зловмисник не зможе здійснити приміром злочинну заміну інформащії, при цьому вчинивши протиправне діяння, за що понесе кримінальну відповідальність, що по суті характеризуе «ідеальний» захист системи блокчейн в сучасних умовах існування, коли злочин не завдав шкоди попри всі необхідні дії, а злочинець несе відповідальність за протиправне діяння. При цьму, така характеристика мережі блокчейн говорить про можливість використання його «протекторату" для захисту інших прав. I тут виникае дуже цікава "колізія», яка може стати неймовірною інновацією у галузі захисту права. Дуже яскравий та ак- туальний приклад - це проблеми захисту інтелектуального права, яке наразі захищається в Україні тільки правовими нормами різних галузей права, що однак наразі не є достатньо едективним механізмом захисту. У зв'язці ж з блокчейном, інтелектуальне право набуває кілька рівнів правового (суміжно галузевого) та технологічного захисту, через що, значно складнішим стає сам процес порушення авторського права, а крім того значною мірою збільшуеться відповідальність порушника. Такі ж можливості захисту та оптимізащії стосуються й інших сорер відання держави. По-друге, технологічний та правовий захист блокчейна підкріплюеться фрізичним захистом системи, тобто забезпечивши неможливість фрізичного втручання в роботу блокчейна або фрізичного псування системи (каналів зв'язку, блоків) її захищеність можна вважати абсолютною. На додачу, фізична оболонка блокчейна захищена правовими нормами від викрадення, псування тощо. Отже, можна зробити висновок, що система блокчейн це неймовірно захищена цифрова система, яка направлена на безпечну та дуже якісну роботу з інформащією, відповідно до чого виникає можливість створення надійних, фрункціональних систем щодо організацї та забезпечення найрізноманітніших процесів у будь яких сорерах. Виходячи з останнього, перспективність технології блокчейн в рамках організащії та функціонування держави не викликає сумнівів, а реальність та результативність такого застосування технології обмежується тільки потребами суспільства та політикою держави $[1 ; 2 ; 5 ; 6 ; 12]$.

Якщо говорити про майбутне застосування технології блокчейн на державному рівні, то можна скористатися успішним досвідом інших держав, а також, з урахуванням аналітичних прогнозів щодо розвитку технологій визначити як ще може застосовуватися дана технологія. Особливе місце слід приділити питанню «електронного урядування» (Е-урядування), як одному з найперспективніших напрямків редрормування у провідних державах світу. Виходячи зі змісту технології блокчейн, на державному рівні іï можна застосовувати у таких сферах: Е-урядування, фрінансовий менеджмент, інформаційне та матеріально-технічне забезпечення процесів організації та фрункціонування держави (здійснення влади). Також, можна зробити висновок про те, що блокчейн $е$ технологічною основою для впровадження інших технологій в сфреру державного управління. Враховуючи особливості технологї блокчейн, пов'язані з можливостями створення, поширення та захисту інформації, саме в цьому напрямку слід прогнозувати його застосування на рівні держави. По-перше, дана технологія дозволяе вивести на новий рівень прозорість публічних процесів. Сутність інновації полягає у тому, що інфрормація про будь-які відповідні процеси (державні закупівлі, міжфондові транзакції, виділення коштів 3 бюджету тощо) буде повністю відкритою, при цьому вона не підлягатиме жодному редагуванню (втручанню), а формуватися така інформацію буде із першоджерела. По-друге, технологія блокчейн може стати ключовим фрактором при вирішенні найрізноманітніших проблем, причиною яких е людський фрактор. Приміром, в питання загальнонаціональної проблеми масової корупції інструменти блокчейна можуть фрактично витіс- 
нити можливість здійснювати корупщійні правопорушення, адже процеси, в ході реалізації яких такі порушення відбувалися можуть стати крім того, що повністю відкритими, ще й частково автоматизованими в необхідній частині. Також, людський фрактор в процесах державного управління породжуе й інші проблеми, приміром надмірну бюрократію тощо $[3 ; 4 ; 5 ; 8 ; 10]$.

Якщо говорити про конкретні сорери впровадження блокчейну, то перше, що спадає на думку - документообіг. Тут же фрункція прозорості, протидії корупщії та зменшення бюрократії. Блокчейн, окрім створення захищених каналів зв'язку між державними установами, дозволяе автоматизувати процеси створення, реєстрації та поширення нормативних документів та інфрормаційних пакетів між установами та в їх внутрішніх структурах. Крім того, в такому ж порядку можна перевести на блокчейн вже існуючу сферу електронних державних фрункцій, що посилить їх ефективність та захищеність [3; 4; 5].

Прикладом роботи таких інноващій $є$ досвід Естонії, де документообіг на основі блокчейну вже реалізований і працюе. Дійсно, як показує статистика, бюрократичні процеси значно прискорились, а крім того збільшилась ефрективність роботи відповідних державних установ. Серед додаткових переваг, така система дозволила зменшити фрінансові витрати на забезпечення бюрократичних процесів у державі. Також, в Швеції реалізовано технологію електронних державних фрункцій на основі блокчейну, що також призвело до покращення їх роботи. Крім того, виключення людського фрактору (або його повний контроль) дозволить попередити махінації 3 державними коштами, повноваженнями державних органів, майном держави, фрізичних та юридичних осіб тощо. Якщо говорити про можливості блокчейна дуже цікавим $є$ його застосування в сфері медицини. Окрім оптимізації інформаційної інфраструктури даної сфери, відкриваються нові можливості прозорого ведення реальної статистики роботи закладів та їх матеріального забезпечення. Крім того, питання захищеності лікарської таємниці також виходить на новий рівень. Такий досвід уже є у Голландії, де крім того, блокчейн використовують для полегшення доступу населення до медичних послуг. Взагалі якщо говорити про охоронювані данні, то блокчейн виключає можливість фізичного витоку (викрадення даних), а також попереджує зловживання правом доступу до такої інформації уповноважених осіб. Проблема дійсно актуальна, враховуючи загальну доступність послуг 3 продажу інформащї̈, яка 3 різних причин охороняеться законом $[2 ; 3 ; 4 ; 5 ; 8]$.

Особливо актуальним сьогодні для вітчизняного простору є організація ринку землі, де блокчейн може зіграти дуже важливу роль. Враховуючи проблеми кадастрового обліку блокчейн $є$ необхідний на всіх етапах, від формування кадастрових відомостей до організації процесів торгівлі 3 подальшим контролем. Така система дозволить уникнути зловживаннями правами щодо купівлі та використання земель на території України. Цікавий досвід має Гана, в якій окрім перелічених функцій блокчейн також використовуеться для вирішення спірних моментів (спорів) про право на землю. В Україні, в свою чергу, Державний зе- мельний кадастр України частково працюе з використанням даної технології $[2 ; 3 ; 4 ; 8 ; 14]$.

Не менш актуальним є також питання проведення виборів та рефререндумів в Україні. Щодо другого, то наразі гострою є проблема фрактичної відсутності механізму проведення референдумів, а також, загальною, не лише для України є проблема втручання в чесні голосування. Тут блокчейн дозволяе вирішити одразу всі проблеми, завдяки власному функціоналу. На основі даної технології можна організувати якісну систему електронного голосування - прозору та фрункціональну. Успішний досвід у цьму напрямку має Естонія, в цій країні запущена система E-voting, як локальний аналог майбутньої державної системи електронного голосування. В США ж уже запущена повномасштабна система електронного голосування на основі технології блокчейн $[5 ; 6 ; 8]$.

Якщо говорити про використання блокчейну в сорері економіки, то крім посилення контролю за процесами документообігу також виникає можливість забезпечення проведення чесних державних аукціонів та тендерів. Приклад - це система E-Auction 3.0 запущена в Таллінні. Ще однією важливою сферою є освіта і тут можна визначитись, що блокчейн дозволить забезпечити фрункціонування чесної системи екзаменування, а також дозволить створити захищену і відкриту базу даних дипломів та сертифікатів, що дозволить захистити права учасників освітніх процесів, а крім того, зручно для роботодавців $[5 ; 6 ; 8 ; 14]$.

Велике значення блокчейн також має для оптимізації всіеї державної системи. Окрім електронного документообігу та підвищення ефрективності їх роботи блокчейн можна використати для налагодження міжвідомчих каналів зв'язку, а також для прямих зв'язків організацій 3 державними фондами тощо. Такі інноващії матимуть дуже багато позитивних наслідків, серед яких найважливішими e якісна оптимізація та організаційно-фрункціональне здешевлення державного забезпечення власного апарату. Таким чином, можна бачити, що застосування технології блокчейн більш ніж реальне вже сьогодні, про що свідчить успішний досвід різних держав, а потенщіал такого застосування обмежений лише уявою управлінців та потребами людського населення $[5 ; 8 ; 14]$.

В Україні, не дивлячись на відсутність нормативної основи технологія блокчейн також все більш активно використовуеться. На рівні держави дана технологія застосовуеться більше як експеримент, хоча вже є реальні результати, а крім того в цивільному секторі економіки блокчейну також знайшлося застосування. В Україні блокчейн вже застосовується в таких сфрерах державного відання: Державний аукціон 3 продажу конфіскованого майна «Сетам»; Відкрита платформа електронної демократії E-vox (ініціатива яка знаходиться на етапі розробки та попереднього тестування на місцях); Національний банкінг (прямування на розвиток безготівкової економіки, розробка конщепції національної валюти - е-гривні); банкінг (впровадження системи Smart Money, впровадження електронних валют в банкінг); Електронний Уряд (розробка концептуального проекту електронного уряду - E-Ukraine на основі блокчейну) та інші галузі $[5 ; 6 ; 7 ; 8 ; 14]$.

Згідно з останніми масштабними дослідженнями, на момент 2018 року Україна потрапила 
до списку 14 країн, які є лідерами із впровадження блокчейну.

Ще у березні 2016-го в місті Києві був підписаний Меморандум про розвиток і впровадження системи децентралізованих онлайн-аукціонів в державних галузях, відповідно до чого було запущено Платформу Eauctoin 3.0, а вже у липні 2016 року відбувся перший блокчейн-аукціон, якій дозволив здавати в оренду державне майно. У квітні 2017 року уряд уклав угоду з американською компанією BitFury про переведення державних реєстрів на блокчейн-платформу, а у жовтні Міністерство аграрної політики та Агентство з питань електронного уряду запустили оновлений Державний земельний кадастр. На момент 2020 року, коли Українське законодавство почало регулювати питання криптовалют, а також державна політика спрямована на переймання зарубіжного досвіду впровадження нових технологій на рівні держави та на розробку власних технологій питання технології блокчейн стало ще більш актуальним та поширеним. В цивільному секторі економіки блокчейн також поступово шириться, так на момент піку популярності технологіі в Україні, у 2017 році, за даними Асоціації Блокчейн України було засновано $32 \%$ усіх компаній, які застосовують технологію блокчейн. Більшість засновників українських блокчейн-компаній прийшли до сорери 3 програмування та розробки (38\%); фрінансів, інвестищій та трейдингу (38\%); криптографрiї та криптовалют (32\%); маркетингу та реклами (12\%). Так можна бачити, що блокчейн технологія, окрім того що охоплюе дуже важливі сорери џивільного сектору економіки, також охоплюе значну їх частину $[5 ; 6 ; 7 ; 8 ; 14]$.

Так, можна бачити, що технологія блокчейн має безліч можливостей до застосування, а у нашої держави, крім того, є великий потенціал, адже вже зараз наша держава стоїть у відповідних рейтингах поруч зі світовими лідерами, такими як США, Китай, Японія, OAE, Британія та інші. Відкритим же лишаеться питання масштабного впровадження даної технології, яке потребуе в першу чергу діяльності по напрямкам забезпечення роботи технології: створення нормативної основи (розробка новітнього законодавства, за прикладом США, врегулювання процесуальної сторони застосування технології блокчейн, адаптація суміжних норм законодавства до інновацій) та технологічно-фрінансове забезпечення (інвестування в оновлення метеріального (технічного) забезпечення, розробка власних технологій, вирішення питання технологічної грамотності населення, особливо публічних службовців). Окрім зазначених особливостей блокчейн має ще одну, a caме, технологія блокчейн відкриває можливість застосування інших технологій (цифрових, комп'ютерних) в галузі управління державою. Технологіями, які потенційно можуть стати реальними складовими державного апарату є штучний інтелект $[5 ; 6 ; 7 ; 8 ; 9 ; 10 ; 14]$.

Перш за все слід зазначити, що питання штучного інтелекту $є$ неймовірно спірним і дискутивним, попри це, в різних частин світу прямо зараз дана технологія активно розвивається i впроваджуеться у найрізноманітніші сорери людського життя, а останнім часом особливий акцент робиться на управлінських процесах. Та- кож важливо відмітити перспективність цієї технології у будь-якій сфрері впровадження через їі фактично необмежений функціонал $[10 ; 11 ; 13]$.

Якщо ж говорити про те що являе собою штучний інтелект сьогодні, то варто зазначити, що цим словосполученням називають різні технології, однак основною з них є нейронні мережі (найбільш досконалий сьогодні прототип штучного інтелекту). Штучний інтелект сьогодні навчають виконувати найрізноманітніші фрункції і в майбутньому прогнозуеться що він буде виконувати переважну більшість всіх робіт, в тому числі приймати участь у розробщі ще більш досконалого штучного інтелекту, що не дивно, враховуючи що сьогодні вже є моделі здатні створювати шедеври мистецтва, проводити складні розрахунки, прогнозувати події тощо $[10 ; 11 ; 13]$.

Ставлення до таких технологій звісно різне, що зрозуміло, однак поки одні держави говорять про небезпеку таких інновацій інші активно їх розвивають i скрізь впроваджують. Перше, що спадає на думку це звісно ж США, де нещодавно штучний інтелект (далі - ШІ) набув офіційного статусу, адже там розвиток даної технології іде неймовірними темпами, вона вже впроваджуеться у сфреру урядування, медицини збройних сил, економіки тощо. З 2017 року Ш в США врегульований відповідним актом, а наразі навіть тривають дискусії про присвоєння Ш прав, таких же як у людей, зокрема акцент робиться на свободі Ш та авторських правах. Досвід США перш за все доводить можливість застосування такої технології, він же дає приклад правильного застосування i демонструе усі переваги від співпраці людини з ШІ. Говорячи про ШІ в сорері державного управління США, наразі в кількох штатах діють кілька проектів, подібних між собою. Суть цих проектів полягає в тому, що Ш або застосовують для різних організаційних процесів або навіть передають право здійснення безпосереднього управління. Щодо першого, то ШІ використовуеться для автоматизації організаційних заходів у різних державних органах, в тому числі щодо документообігу, аналізу статистики тощо $[10 ; 11 ; 12 ; 13]$.

Інша річ це застосування технології для безпосереднього здійснення управлінських функцій, шляхом прив'язки ШІ до якоїсь публічної посади або взагалі заміни такої посади ШІ. Штучний інтелект, як показуе досвід США, Ш здатен повністю виконувати управлінські функції, а саме приймати рішення щодо якихось проблемних питань, організовувати роботу органів, складати плани розвитку, економічні плани, віддавати накази компетентним особам, складати звіти і навіть приймати рішення про преміювання чи накладання стягнень на особовий склад. Як і у випадку з блокчейном, Ш якісно впливає на людський фрактор у роботі управління, однак, якщо блокчейн його обмежуе, то Ш його виносить на новий рівень. Звісно ж тут вбачаються неймовірні переваги, окрім підвищення якості управління, його ефективності та інших якісних змін, також вирішуеться велика кількість проблем людського фактору, а блокчейн остаточно захистить систему від стороннього втручання. Що тут казати, якщо прямо зараз триває дискусія про використання ШІ в якості судді, і не дивлячись на попередню скептику, можливо це реальний шлях до ство- 
рення незалежного і безстороннього суду. Стаття 6 Свропейській конвенщії про захист прав людини та основоположних свобод закріплюе право розгляду справ незалежним і безстороннім судом і не вказуе що суддею повинна бути обов'язково людина. Хоча, нащіональне законодавство, зокрема ст. 127 Конституції України встановлюе таке правило, як і законодавство інших держав, що на практищі не перешкоджає впровадженні технології, як допоміжної в систему правосуддя $[10 ; 11 ; 13 ; 15]$.

Висновки і пропозиції. ШІ це майбутне, яке однак починається вже сьогодні, що звісно потребуе попередньої підготовки, як і у випадку із блокчейном. Що однак $є$ перспективним напрямком держави і людства в цілому. Таким чином, можна зробити висновок про те, що сучасні цифрові технологї, зокрема блокчейн та Ш не просто можливість, а необхідність, яка крім того що дозволить вирішити глобальні проблеми також виведе інститут держави на новий рівень i забезпечить розвиток усіх copep. Блокчейн це безпека, якість та надійність, яких сьогодні так не вистачає в системі держави, а також це шлях до розвитку і прогресу, якого всі так прагнуть.

\section{Список літератури:}

1. Про телекомунікації : Закон України від 18.11.2003 № 1280-IV. Верховна Рада України. URL: https://bitly.su/ 9S525 (дата звернення: 22.03.2021).

2. Технология Blockchain простыми словами. DNS клуб. URL: https://bit.ly/3cZVHAc (дата звернення: 22.03.2021).

3. Какое влияние блокчейн окажет на систему государственного управления. CryptoPerson. URL: https://bit.ly/ 3f2b6CT (дата звернення: 22.03.2021).

4. Дмитрий Шустов. Как использовать блокчейн на уровне государства. EX4.ru. URL: https://bit.ly/3cUqC10 (дата звернення: 22.03.2021)

5. Ключ до світового лідерства: Чому країни посилено розвивають штучний інтелект. 112.ua. URL: https://bit.ly/ $3 \mathrm{vNWuNb}$ (дата звернення: 22.03.2021).

6. Петро Біда, Ольга Петрова. Технологія блокчейн та їі використання у державному Земельному кадастрі та землеустрою. URL: https://bit.ly/313Q4LZ (дата звернення: 22.03.2021).

7. "Попереду планети всіеі": які компанії займаються блокчейном в Україні. Економічна правда. URL: https://bit.ly/3lE0RG4 (дата звернення: 22.03.2021).

8. Блокчейн у держструктурах: які країни вже використовують технологію. Слово і діло. URL: https://bit.ly/ 3c7iaMu (дата звернення: 22.03.2021).

9. Гапеєв Леонід. Електронне урядування: проблеми, пріоритети, завдання. Держслужбовець, Березень, 2018. № 3. IFactor. URL: https://bit.ly/3cc450у (дата звернення: 22.03.2021).

10. Гевко I. Б. Переваги та недоліки застосування штучного інтелекту у сферах управління. URL: https://bit.ly/ 3tKbjyF (дата звернення: 22.03.2021).

11. Уряд США визначив, що таке штучний інтелект. Tehnot. URL: https://bit.ly/3vP8PAU (дата звернення: 22.03.2021).

12. Костянтин Докійчук. Деякі питання деліктоздатності штучного інтелекту. Судебно-юридическая газета. URL: https://bit.ly/3cQy39m (дата звернення: 22.03.2021).

13. Світлана Тартасюк. Штучний інтелект: майбутне фінансової системи та економіки. Мінфін. URL: https://bit.ly/ 3tDp6H8 (дата звернення: 22.03.2021).

14. Бондаренко Олексій Вікторович. Запровадження технології блокчейн у державному секторі. Протокол. URL: https://bit.ly/3lFNCET (дата звернення: 22.03.2021).

15. Валерія Шемшученко. Штучний інтелект у правосудді. Центр демократії та верховенства права. URL: https://bit.ly/3lF7hVn (дата звернення: 22.03.2021).

\section{References:}

1. On Telecommunications: Law of Ukraine No. 1280-IV of 18.11.2003. Verkhovna Rada of Ukraine. URL: https://bitly.su/9S525 (accessed 22 March 2021).

2. Blockchain Technology in simple words. DNS club. URL: https://bit.ly/3cZVHAc (accessed 22 March 2021).

3. What impact will the blockchain have on the public administration system? CryptoPerson. URL: https://bit.ly/ 3f2b6CT (accessed 22 March 2021).

4. Dmitry Shustov. How to use blockchain at the state level. EX4.ru. URL: https://bit.ly/3cUqC10 (accessed 22 March 2021).

5. The key to global leadership: why countries are actively developing artificial intelligence. 112.ua. URL: https://bit.ly/ 3vNWuNb (accessed 22 March 2021).

6. Peter Beda, Olga Petrova. Blockchain technology and its use in the state land Cadastre and Land Management. URL: https://bit.ly/313Q4LZ (accessed 22 March 2021).

7. "Ahead of the rest of the planet": what companies are engaged in blockchain in Ukraine. Economic truth. URL: https://bit.ly/3lE0RG4 (accessed 22 March 2021).

8. Blockchain in government agencies: which countries already use the technology. Word and deed. URL: https://bit.ly/ 3c7iaMu (accessed 22 March 2021).

9. Leonid Gapeev. E-governance: problems, priorities, and tasks. Civil Servant, March, 2018. No. 3. Ifactor. URL: https://bit.ly/3cc450y (accessed 22 March 2021).

10. Gevko I. B. advantages and disadvantages of using artificial intelligence in management spheres. URL: https://bit.ly/3tKbjyF (accessed 22 March 2021).

11. The US government has defined what artificial intelligence is. Tehnot. URL: https://bit.ly/3vP8PAU (accessed 22 March 2021).

12. Konstantin Dokiychuk. Some questions about the tort capacity of artificial intelligence. Sudebno-yuridicheskaya Gazeta. URL: https://bit.ly/3cQy39m (accessed 22 March 2021).

13. Svetlana Tartasyuk. Artificial intelligence: the future of the financial system and economy. Ministry of Finance. URL: https://bit.ly/3tDp6H8 (accessed 22 March 2021).

14. Alexey Viktorovich Bondarenko. Introduction of blockchain technology in the public sector. Protocol. URL: https://bit.ly/3lFNCET (accessed 22 March 2021).

15. Valeria Shemshuchenko. Artificial intelligence in Justice. Center for democracy and the rule of law. URL: https://bit.ly/3lF7hVn (accessed 22 March 2021). 